\title{
In Vitro Evaluation of Botanicals, Bio-Agents and Fungicides against Leaf Blight of Etlingera linguiformis Caused by Curvularia lunata Var. Aeria
}

Chijamo Kithan* and Daiho L

Department of Plant Pathology, School of Agricultural Sciences and Rural Development, Nagaland University, Medziphema Campus, Nagaland, India

*Corresponding author: Chijamo Kithan, Department of Plant Pathology, School of Agricultural Sciences and Rural Development, Nagaland University, Medziphema Campus, Nagaland-797106, India, Tel: 03862-247264; E-mail: chijamokyong@ymail.com

Rec date: Jul 10, 2014, Acc date: Sep 24, 2014, Pub date: Sep 28, 2014

Copyright: $\odot 2014$ Kithan C, et al. This is an open-access article distributed under the terms of the Creative Commons Attribution License, which permits unrestricted use, distribution, and reproduction in any medium, provided the original author and source are credited.

\begin{abstract}
The present study was attempted with the objective of screening the potential antifungal activities of eight fungicides, nine plant extracts and five bio-agents in vitro against leaf blight of $E$. linguiformis caused by $C$. lunata var. aeria. Mancozeb at $0.3 \%(97.37 \%$ inhibition) was found to be significantly superior among the non-systemic fungicides evaluated at three concentrations $(0.1,0.2$ and $0.3 \%)$. Among the systemic fungicides, metalaxyl showed $98.48 \%$ inhibition of mycelial growth at $0.3 \%$ concentration followed by carbendazim $(95.25 \%$ inhibition at $0.3 \%)$. Among the plant extracts, Millettia pachycarpa root extracts (55.78) at 10 per cent was superior followed by Acorus calamus with $53.40 \%$ inhibition at 10 per cent. Among the bio-agents tested, Trichoderma harzianum showed maximum inhibition of 68.85 per cent inhibition. The study indicated that suitable integration of more efficient ecofriendly treatments like bio-agents and botanicals with lesser use of fungicides may provide effective management of the disease.
\end{abstract}

Keywords: Etlingera linguiformis, Curvularia lunata var. aeria; Leaf blight; Fungicides; Bio-agents; Plant extracts

\section{Introduction}

Etlingera linguiformis (Roxb.) R.M.Sm of Zingiberaceae family is an important indigenous medicinal and aromatic plant found in Nagaland. The plant species was identified from Botanical Survey of India, Eastern Regional Centre, Shillong. A voucher specimen (BSI/ERC/2014/Plant identification/883) has been deposited in the herbarium of the Botanical Survey of India, Shillong. It grows well in warm climates with loamy soil rich in humus. The entire plant is aromatic. The rhizome of the plant is used medicinally to treat sore throat, stomachache, rheumatism and respiratory complains etc. The aromatic rhizome of E. linguiformis contains an essential oil used in perfumery. Young leaves and shoots are used as leafy vegetables. Rhizomes are used as medicine to cure jaundice [1]. Recently, severe symptoms typically of Curvularia leaf blight were observed. The disease is mainly a foliar disease. Leaf blight of Curvularia species have been reported as casual agents of leaf spots and leaf blight [2]. Initial symptoms of the disease are small brown water soaked flecks appears on the upper leaf surface with diameter ranging from 0.5 to $3 \mathrm{~cm}$ which later coalesced to form dark brown lesions with a well-defined border. Lesions often merged to form large necrotic areas, covering more than $90 \%$ of the leaf surface, which contributed to plant death. The pure culture of the fungus was examined under microscope and identified as Curvularia lunata var.aeria. The morphological authenticity of the isolated fungus was confirmed from the Indian Type Culture Collection, Division of Plant Pathology, Indian Agriculture Research Institute, New Delhi (ITCC Accession No. 7895.10). Further molecular identification was done through DNA sequencing by using primers ITS4 and ITS5 from the Microbial Type Culture Collection \& Gene Bank at the Institute of Microbial Technology (IMTECH), Chandigarh, India (Accession No.
MTCC11875). The disease significantly reduces the number of functional leaves. Late in the disease progression, stems and rhizomes were also affected thereby reducing oil yield and quality. Leaf blight of Java citronella (Cymbopogon winterianus Jowitt.), caused by Curvularia spp., and was found to cause a dramatic change in oil yield and its constituents [3]. It was also observed that Curvularia leaf blight infection increased with the age of the crop. Therefore, in view of the magnitude of damage caused by the fungus on this important plant, the present investigation was undertaken to screen out the most efficient fungicides, botanicals and bioagents against $C$. lunata var. aeria for field management of the disease.

\section{Materials and Methods}

The present investigation on in vitro bioassay of different fungicides, botanicals, and bioagents was carried out at the Department of Plant Pathology, School of Agricultural \& Rural Development, Nagaland University during 2011-2012. Eight fungicides consisting of four systemic and four non-systemic were assayed for their efficacy against $C$. lunata var. aeria under in vitro condition. Each of the fungicides were tested at $0.1,0.2,0.3$ per cent concentrations. The poisoned food technique was adopted for in vitro testing of fungicides [4]. The calculated quantities of fungicides were thoroughly mixed in the medium before pouring into Petriplates so as to get the desired concentration of active ingredient of each fungicide separately. Twenty $\mathrm{ml}$ of fungicide amended medium was poured in each of $90 \mathrm{~mm}$ sterilized Petriplates and allowed to solidify. The plates were inoculated centrally with $8 \mathrm{~mm}$ disc of 10 days old young sporulating culture of $C$. Iunata var. aeria. Controls without fungicides were also maintained. The experiment was conducted in Completely Randomised Design (CRD) with three replications in each treatment. The inoculated petriplates were incubated at $25 \pm 2^{\circ} \mathrm{C}$. The colony diameters were measured after 10 days when the control plates were full of fungal growth. Per cent inhibition of growth was calculated by using formula given by Vincent [5]. 
Citation: Kithan C and Daiho L (2014) In Vitro Evaluation of Botanicals, Bio-Agents and Fungicides against Leaf Blight of Etlingera linguiformis Caused by Curvularia lunata Var. Aeria. J Plant Pathol Microbiol 5: 232. doi:10.4172/2157-7471.1000232

Page 2 of 6

\section{$\mathrm{I}=[(\mathrm{C}-\mathrm{T}) /(\mathrm{C})] \mathrm{X} 100$}

Where, I=Per cent inhibition; $\mathrm{C}=$ Colony diameter in control; $\mathrm{T}=$ Colony diameter in treatment

Plant tissues was grounded using pestle and mortar by adding equal amount of sterilized distilled water $(1: 1 \mathrm{w} / \mathrm{v})$. The extract was filtered through muslin cloth. The supernatant was taken as standard plant extract solution (100\%). Further, the extract was diluted by adding sterilised water to get $5,7.5$ and 10 per cent concentrations respectively. The plant extracts were subjected to heating to $50^{\circ} \mathrm{C}$ in water bath to avoid contamination and then incorporated into PDA medium by transferring $2 \mathrm{ml}$ of each type of plant extracts into a Petridish containing $20 \mathrm{ml}$ melted warm PDA medium and gently shaken for thorough mixing of the extract. The PDA plates containing the plant extracts were inoculated aseptically with $C$. lunata var. aeria by transferring $8 \mathrm{~mm}$ diameter agar disc of 10 days old culture of the pathogen to the center of PDA medium in Petridish. Three replications were maintained for each treatment. The basal medium (PDA) without any plant extract was served as control. All the inoculated Petridishes were incubated at $25 \pm 2^{\circ} \mathrm{C}$. The radial growth of the test fungus in the treated plates was measured when the pathogen growth touched the periphery in the control Petridishes. The per cent inhibition of fungal growth was estimated by using the formula given by Vincent [5].

Five bioagents, Trichoderma harzianum, Trichderma viride, Trichoderma koningii, Pseudomonas fluorescens and Bacillus subtilis at $10^{8}$ spores/ml were evaluated against $C$. lunata var. aeria by dual culture technique. The bio-agents as well as the test pathogen were inoculated equidistant on PDA medium aseptically and incubated at $28 \pm 2^{\circ} \mathrm{C}$. Three replications were maintained along with untreated control. After obtaining the maximum growth in the control, the zone of inhibition was recorded by measuring the clear distance between the margin of the test fungus and antagonistic organisms. The colony diameter of pathogen in control plate was also recorded. The per cent inhibition of the growth of the pathogen was calculated by using the formula suggested by Vincent (Figures 1-5) [5].

\section{Statistical analysis}

The statistical analysis of obtained results was carried out by using SPSS (Statistical Package for the Social Sciences) Version 16.0 software. Per cent data were transformed to arc sine values and analyzed statistically.

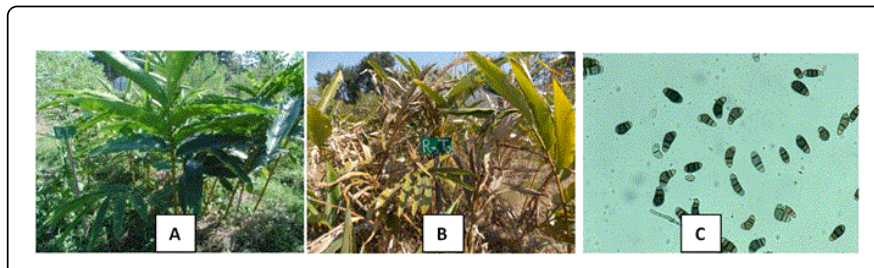

Figure 1: Showing the following- Plate 1: A-Healthy Plant, B-Leaf blight infection, C- Curvularia lunata var. aeria

\begin{tabular}{|c|c|c|c|c|c|}
\hline \multirow{2}{*}{$\frac{\text { SI.No }}{1}$} & \multirow{2}{*}{$\begin{array}{l}\text { Treatments } \\
\text { Non systemic fungicides }\end{array}$} & \multicolumn{4}{|c|}{ Per cent inhibition Concentration (\%) } \\
\hline & & 0.001 & 0.002 & 0.003 & Mean \\
\hline \multirow[t]{2}{*}{1} & \multirow[t]{2}{*}{ Captan } & 29.86 & 44.96 & 76.56 & \multirow[t]{2}{*}{50.46} \\
\hline & & -33.1 & -42.11 & -61.06 & \\
\hline \multirow[t]{2}{*}{2} & \multirow[t]{2}{*}{ Chlorothanil } & 24.13 & 40.65 & 61.82 & \multirow[t]{2}{*}{42.2} \\
\hline & & -29.41 & -39.61 & -51.84 & \\
\hline \multirow[t]{2}{*}{3} & \multirow[t]{2}{*}{ Copper oxychloride } & 33.16 & 52.79 & 91.6 & \multirow[t]{2}{*}{59.18} \\
\hline & & -35.15 & -46.6 & -73.18 & \\
\hline \multirow[t]{2}{*}{4} & \multirow[t]{2}{*}{ Mancozeb } & 43.79 & 64.62 & 97.37 & \multirow[t]{2}{*}{68.59} \\
\hline & & -41.43 & -53.5 & -80.77 & \\
\hline II & Systemic fungicides & & & & \\
\hline \multirow[t]{2}{*}{1} & \multirow[t]{2}{*}{ Carbendazim } & 51.32 & 76.78 & 95.25 & \multirow[t]{2}{*}{74.45} \\
\hline & & -45.76 & -61.21 & -77.47 & \\
\hline \multirow[t]{2}{*}{2} & \multirow[t]{2}{*}{ Hexaconazole } & 41.49 & 53.94 & 90.34 & \multirow[t]{2}{*}{61.92} \\
\hline & & -40.09 & -47.26 & -71.99 & \\
\hline \multirow[t]{2}{*}{3} & \multirow[t]{2}{*}{ Metalaxyl } & 60.87 & 79.87 & 98.48 & \multirow[t]{2}{*}{79.74} \\
\hline & & -51.29 & -63.36 & -83.01 & \\
\hline \multirow[t]{2}{*}{4} & \multirow[t]{2}{*}{ Mycobutanil } & 25.16 & 41.08 & 51.06 & \multirow[t]{2}{*}{39.1} \\
\hline & & -30.1 & -39.86 & -45.6 & \\
\hline
\end{tabular}


Citation: Kithan C and Daiho L (2014) In Vitro Evaluation of Botanicals, Bio-Agents and Fungicides against Leaf Blight of Etlingera linguiformis Caused by Curvularia lunata Var. Aeria. J Plant Pathol Microbiol 5: 232. doi:10.4172/2157-7471.1000232

Page 3 of 6

\begin{tabular}{|l|l|l|}
\hline & $\mathrm{CD}(\mathrm{p}=0.05)$ & 3.57 \\
\hline & S.Em \pm & 4.72 \\
\hline & $\mathrm{CV} \%$ & 3.65 \\
\hline
\end{tabular}

Table 1: In vitro evaluation of fungicides against $C$. lunata var.aeria, E. linguiformis leaf blight pathogen. ${ }^{\star}$ Figure in parenthesis is arcsine transformations.

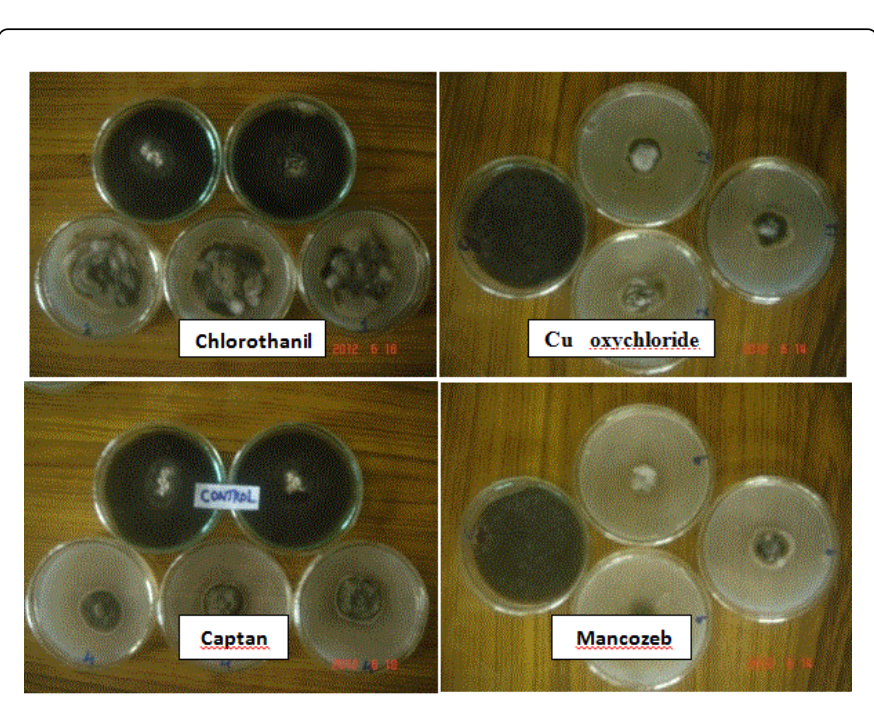

Figure 2: Non-Systemic fungicide
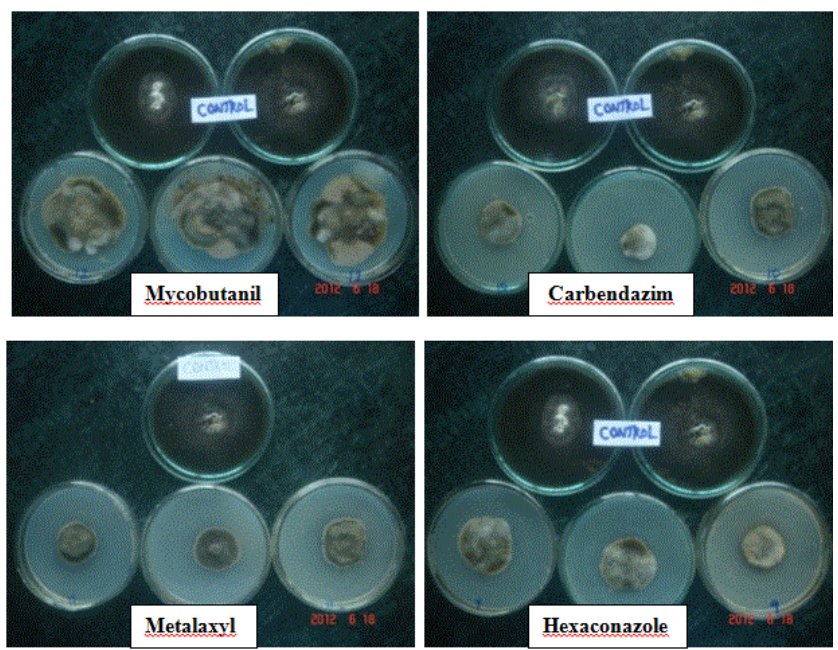

Figure 3: Systemic fungicides

\section{Results and Discussion}

In vitro evaluation of provides useful and preliminary information regarding efficacy of fungicides. Plant extracts and bio-agents against pathogen within a shortest period of time and therefore, serves as a guide for field testing. Chemical control measures have been tested and found effective in the control of diseases [6,7]. Certain protective fungicides although hazardous to environment are still used for the control of fungal diseases [8].

In the present investigation, four systemic fungicides and four nonsystemic fungicides were tested at three concentrations (Tables 1-3). Among the non-systemic fungicides tested, mancozeb and copper oxychloride was found to be most effective in inhibiting the mycelia growth at all three concentrations $(0.1,0.2$ and $0.3 \%)$ with inhibition of $97.37 \%$ and $91.60 \%$ respectively.

\begin{tabular}{|c|c|c|c|c|c|c|}
\hline \multirow{2}{*}{$\begin{array}{l}\text { SI.N } \\
0\end{array}$} & \multirow{2}{*}{ Plant extracts } & \multicolumn{3}{|c|}{$\begin{array}{l}\text { Per cent inhibition of } \\
\text { Concentrations }(\%)\end{array}$} & mycelia & growth \\
\hline & & Parts used & 5 & 7.5 & 10 & Mean \\
\hline \multirow{2}{*}{1} & \multirow{2}{*}{ Acorus calamus } & \multirow{2}{*}{ Rhizome } & 29.61 & 45.21 & 53.4 & 42.74 \\
\hline & & & -32.95 & -42.3 & -47 & \\
\hline \multirow{2}{*}{2} & \multirow{2}{*}{ Allium sativum } & \multirow{2}{*}{ Bulb } & 22.82 & 30.58 & 44.11 & 32.5 \\
\hline & & & -28.51 & -33.6 & -41.6 & \\
\hline \multirow{2}{*}{3} & \multirow{2}{*}{ Azadirchta indica } & \multirow{2}{*}{ Leaf } & 17.7 & 27.82 & 42.19 & 28.23 \\
\hline & & & $(22 / 43)$ & -31.8 & -40.5 & \\
\hline \multirow[b]{2}{*}{4} & \multirow[b]{2}{*}{ Curcuma caesia } & \multirow[b]{2}{*}{ Rhizome } & 27.95 & 42.55 & 47.85 & 39.45 \\
\hline & & & -31.91 & -40.7 & -43.8 & \\
\hline \multirow{2}{*}{5} & \multirow{2}{*}{ Curcuma longa } & \multirow{2}{*}{ Rhizome } & 13.15 & 29.86 & 37.33 & 26.78 \\
\hline & & & -21.2 & -33.1 & -37.7 & \\
\hline \multirow{2}{*}{6} & \multirow{2}{*}{ Lawsonia inermis } & \multirow{2}{*}{ Leaf } & 19.41 & 31.11 & 38.32 & 29.61 \\
\hline & & & -26.12 & -33.9 & -38.2 & \\
\hline \multirow{2}{*}{7} & \multirow{2}{*}{$\begin{array}{l}\text { Millettia } \\
\text { pachycarpa }\end{array}$} & \multirow{2}{*}{ Root } & 34.03 & 47.28 & 55.78 & \\
\hline & & & -35.58 & -43.4 & -48.3 & 45.69 \\
\hline \multirow{2}{*}{8} & \multirow{2}{*}{ Oroxylum indicum } & \multirow{2}{*}{ Bark } & 17.47 & 23.68 & 33.55 & \\
\hline & & & -24.68 & -29.1 & -35.4 & 24.9 \\
\hline \multirow{2}{*}{9} & \multirow{2}{*}{ Zingiber officinale } & \multirow{2}{*}{ Rhizome } & 13.13 & 30.34 & 37.42 & \\
\hline & & & -21.21 & -33.4 & -37.7 & 26.96 \\
\hline \multicolumn{2}{|c|}{$C D(p=0.05)$} & \multicolumn{5}{|l|}{3.29} \\
\hline S.Em & & 5.75 & & & & \\
\hline CV\% & & 7.27 & & & & \\
\hline
\end{tabular}

Table 2: In vitro evaluation of different plant extracts against mycelia growth of $C$. lunata var.aeria. * Figure in parenthesis is arcsine transformations. 
Citation: Kithan C and Daiho L (2014) In Vitro Evaluation of Botanicals, Bio-Agents and Fungicides against Leaf Blight of Etlingera linguiformis Caused by Curvularia lunata Var. Aeria. J Plant Pathol Microbiol 5: 232. doi:10.4172/2157-7471.1000232

Page 4 of 6
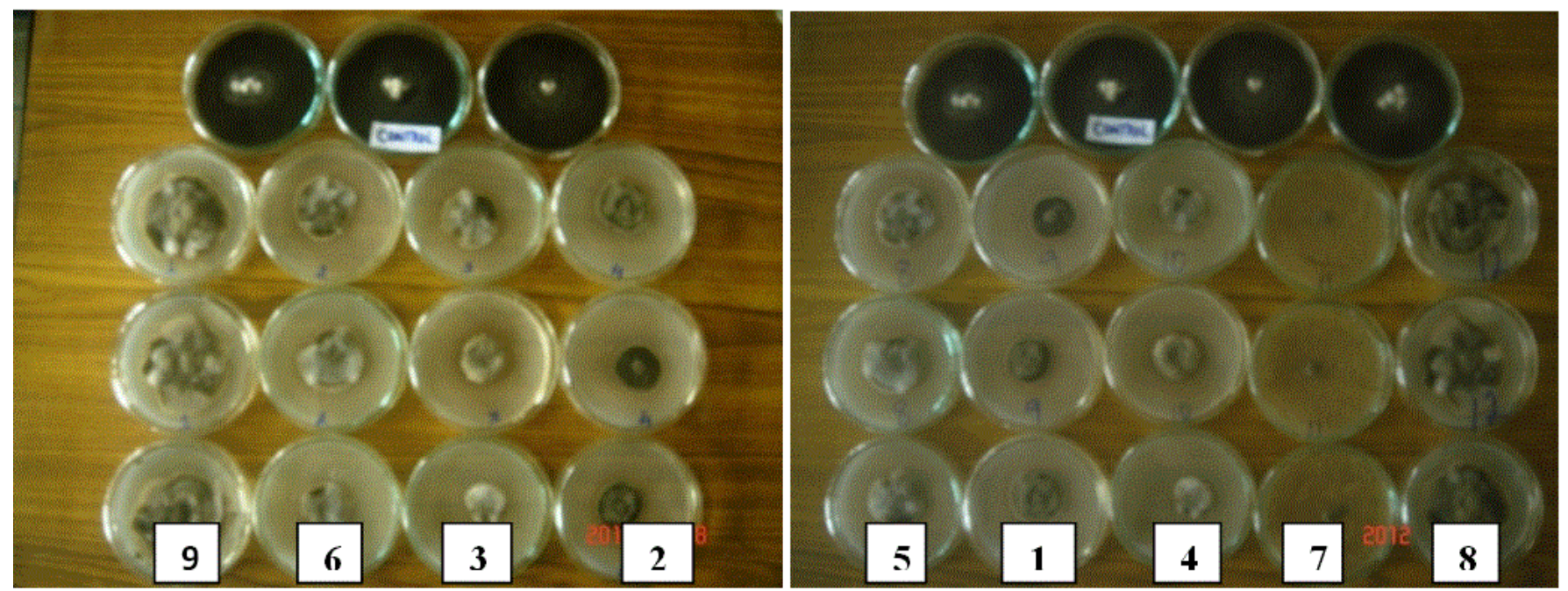

Figure 4: Plant extracts

\begin{tabular}{|l|l|l|}
\hline SI.No & Biocontrol agents & Per cent inhibition of mycelia growth \\
\hline 1 & Trichoderma harzianum & $68.85(56.10)$ \\
\hline 2 & Trichoderma viride & $57.82(49.50)$ \\
\hline 3 & Trichoderma koningii & $48.35(44.05)$ \\
\hline 4 & Pseudomonas fluorescens & $51.36(45.78)$ \\
\hline 5 & Bacillus subtilis & $30.32(33.39)$ \\
\hline & CD ( $\mathrm{p}=0.05)$ & 5.29 \\
\hline & S.Em \pm & 8.47 \\
\hline & CV\% & 5.67 \\
\hline
\end{tabular}

Table 3: In vitro evaluation of biocontrol agents against mycelia growth of $C$. lunata var. aeria, the causal agent of leaf blight of $E$. linguiformis. ${ }^{*}$ Figure in parenthesis are arcsine transformations.

It was followed by captan (76.56\%) at 0.3 per cent. Pawar et al. [9] also reported that eight fungicides were screened against $C$. lunata and C. pallescens. Out of them, mancozeb $(0.2 \%)$, tricyclazole $(0.1 \%)$ and campainion (mancozeb + carbendazim) $(0.25 \%)$ were found effective against $C$. Iunata. Jackson [10] reported that blight disease can be controlled by spraying with copper fungicides. Singh et al. [11] reported that mancozeb was effective against $C$. lunata var. aeria. The least effective among the non-systemic fungicides was chlorothanil (61.82\% inhibition). Among the systemic fungicides, metalaxyl and carbendazim were found to be highly effective in inhibiting the growth of $C$. lunata at $0.3 \%$ concentrations $(98.48 \%$ and $95.25 \%$ inhibition) followed by hexaconazole (90.34\%) at 0.3 per cent. Adejumo [12] reported that the use of fungicides such as copper and copper metalaxyl-based compounds is the most reliable and popular with farmers because of the quick and effective action. Efficacy of these fungicides was previously reported by Sumangala et al. [13] and Jackson [10]. Mycobutanil was found to be the least effective (51.06\% inhibition) among the systemic fungicides evaluated.

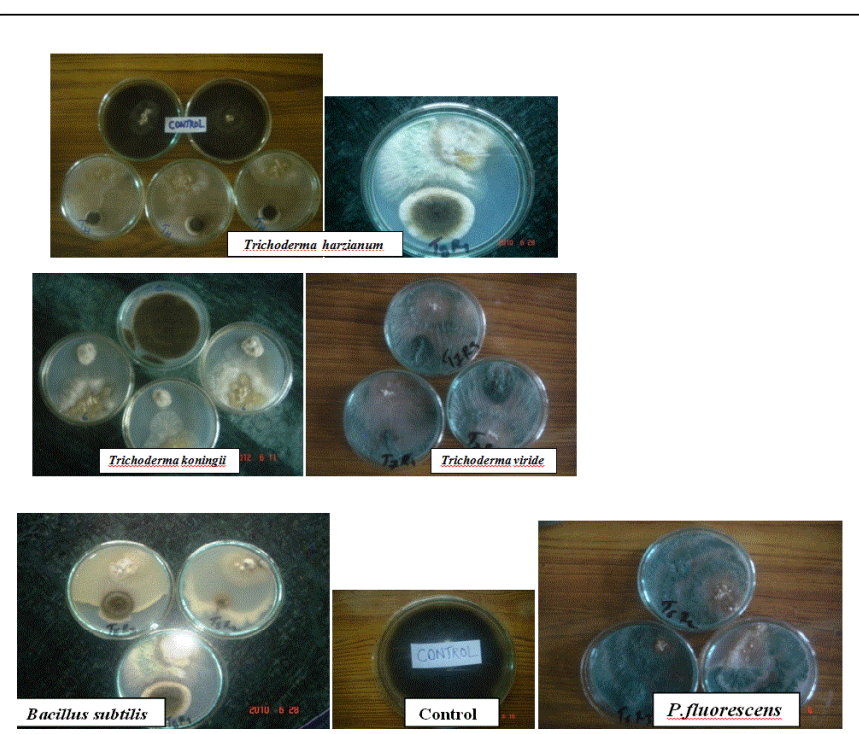

Figure 5: Biocontrol agents

Plant metabolites and plant based pesticides appear to be one of the better alternatives as they are known to have minimal environmental impact and danger to consumers in contrast to synthetic pesticides [14]. Extracts of many higher plants have been reported to exhibit antifungal properties under laboratory $[15,16]$. Plant extracts show antifungal activity against a wide range of fungi [17]. Plants in their natural state possess a relative stable biological balance with microbes on their surface. In the present investigation, though complete inhibition of the fungus was not observed in any of the nine botanicals used, considerable amount of inhibition of growth was noticed in some of the botanicals. Root extracts of $M$. pachycarpa was found to be most effective at all the three concentrations 5\% (34.03\%), $7.5 \%$ (47.28\%), $10 \%(55.78 \%)$ followed by $A$. calamus rhizome extract (53.40\% inhibition) at 10 per cent. The fungicidal effects of Acorus calamus (sweet flag) has already been investigated by Parinthawong 
[18]. Bulb extracts of Allium sativum, Azadirchta indica, Lawsonia inermis and Azadirchta indica are also effective to some extent. Later, Choi et al. [19], Bandara et al. [20] reported Acorus calamus, Zingiber zerumbet and Curcuma longa to possessed several important biological activities including antifungal. Crude extracts of Curcuma longa, Zingiber officinale, Allium sativum, tested in vitro showed significant antifungal activity against Curvularis sp. [21]. Significant inhibition of Dreschlera graminae, Curvularia lunata, Aspergillus fumigatus and Candida albicans were observed with petroleum ether and benzene fractions of the leaf of the leaf of Lawsonia inermis [22]. Pawar et al. [9] reported that Garlic (Allium sativum) completely inhibited the mycelial growth of both pathogenic fungi followed by Azadirachta indica.

Biological control through the use of antagonistic microorganisms is a potential non-chemical means of controlling plant disease by reducing inoculum levels of the pathogens. Such a management would help in preventing the pollution and also health hazards. In the present investigation, the antagonistic effect of different bioagents assessed against $C$. lunata var.aeria by dual culture technique, $T$. harzianum has inhibited maximum growth of fungus with $68.85 \%$ followed by $T$. viride (57.82\%), and P. fluorescens (51.36\%). Bacillus subtilis was found to be the least effective (30.32\%). The inhibitory effect of these bio-agents may be due to competition and antibiosis. Pawar et al. [9] reported that $T$. harzianum and $T$. viride significantly inhibited growth of $C$. lunata in vitro. The present investigations are in agreement with Sumangala et al. [13], who found effectiveness of Trichoderma sp. against $C$. lunata. This could be obviously due to several possibilities of existence of microbial interactions such as stimulation, inhibition, mutual intermingling of growth of antagonistic isolate over test pathogen etc. have been enumerated by many workers [23-25]. The antagonistic activities of $T$. harzianum against several pathogenic fungi have also been reported by many workers [26-28]. The antagonism of Trichoderma spp. against many fungi is mainly due to production of acetaldehyde compound [29]. Sumangala et al. [13] reported that $B$. subtilis, T. viride and T. harzianum were found effective in inhibiting the radial growth of fungus.

\section{Conclusion}

The present study revealed that Metalaxyl and mancozeb @ 0.1 per cent found most effective in inhibiting the growth of $C$. lunata var. aeria. Carbendazim and Hexaconazole both at 0.1 per cent were also found equally effective which can be used as an alternative to mancozeb and metalaxyl. Among the bioagents, Trichoderma harzianum was found to be most effective in inhibiting the mycelial growth. Millettia pachycarpa and Acorus calamus extracts at 5.0 per cent showed maximum growth inhibition among the plant extracts. Thus the study indicated that suitable integration of more efficient eco-friendly treatments like bio-agents and botanicals with lesser use of fungicides may provide a better management of the disease.

\section{References}

1. Ramana MV, Tagore JK, Bhattacharjee A (2012) Report of two medicinal and aromatic gingers from Andaman and Nicobar Islands. India J Threatened Taxa 4: 2582-2586.

2. Benoit MA, Mathur SB (1970) Identification of species of Curvularia on Rice seed. Contribution from the Danish Government Institute of seed pathology for developing countries, Copenhagen, Denmark.

3. Chutia M, Mahanta JJ, Sakia RC, Baruah AKS, Sarma TC (2006) Influence of leaf blight disease on yield and its constituents of Java citronella and in vitro control of the pathogen using essential oils. World Journal of Agricultural Sciences 2: 319- 321.

4. Nene YL, Thapliyal PN (1993) Fungicides in plant diseases control. Oxford and IPH. Publishing Co. Pvt. Ltd., New Delhi PP.531.

5. VINCENT JM (1947) Distortion of fungal hyphae in the presence of certain inhibitors. Nature 159: 850.

6. Ogundana SK, Denis C (1981) Assessment of fungicides for prevention of storage rot of yams. Pesticide Science 11: 491-494.

7. Plumbley RA (1985) Benomyle tolerance in strain of Penicillium sclereteginum infecting yams and use of imazalid as a means of control. Tropical Agriculture Trinidad 61: 182-185.

8. Vaish DK, Sinha AP ( 2003) Determination of tolerance in Rhizoctonia solani, Trichoderma virens and Trichoderma sp. (isolate 20) to systemic fungicides. Indian journal of Plant Pathol 21: 48-50.

9. Pawar DM, Arekar JS, Borkar PG (2012) In vitro evaluation of bioagents and botanicals against Curvularia blight of gladiolus. Journal of Plant Disease Sciences 7: 70-72.

10. Jackson GVH (1996) Strategies for taro leaf blight research in the region. Taro Leaf Blight Seminar. Proceedings. Alafua pp. 95-100.

11. Singh AK, Sinha RKP, Sinha RP (2002) Curvularia lunata: a major pathogen for leaf blight of wheat in Bihar, India. Journal of Applied Biology 5: 83-84.

12. Adejumo TO (1997) Identification, incidence, severity and methods of control of the causal organism of false smut disease of cowpea (vignia unguiculata L.) Walp. PhD Thesis. University of Ibadan, Nigeria 201.

13. Sumangala K, Patil MB, Nargund VB, Ramegowda G (2008) Evaluation of fungicides, botanicals and bio-agents against Curvularia lunata, a causal agent of gain discoloration in rice. Journal of Plant Disease Sciences 3: 159-164.

14. Verma J, Dubey NK (1999) Prospectives of botanical and microbial products as pesticides of tomorrow. Current Science 76: 172-179.

15. Mohana DC, Raveesh KA, Lokanath R (2008) Herbal remedies for the management of seed-borne fungal pathogens. Phytopathology and Plant protection 41: 38-49.

16. Ashwani Tapwal, Nisha, Shipra Garg, Nandini Gauta, Rajesh Kumar (2011) In vitro antifungal potency of plant extracts against five phytopathogens. Braz arch biol technology, 54: 6.

17. Wilson CL, Solar JM, Ghaouth AE, Wisniewski ME (1997) Rapid evaluation of plant extracts and essential oils for antifungal activity against Botrytis cinerea. Plant Disease 81: 201-210.

18. Parinthawong N, Tansian P, Youngnit C (2010) Effects of three plant crude extracts on fungal spore germination and hyphal growthof Curvularia sp. Dept. of Plant Protection Technology, Bangkok, Thailand.

19. Choi GJ, Jang KS, Kim JS, Lee SW, Cho JY, et al. (2004) In vivo antifungal activities of 57 plant Extracts against six plant pathogenic fungi. Journal of Plant Pathology 3: 184-191.

20. Bandara JMRS, Wijayagunasekera NNP (1988) Antifungal activity of some rhizomatous plant extracts. Proceedings of the 5th International congress of plant pathology, Kyoto, Japan.

21. Sanit S (2012) Antifungal activity of twenty four medicinal crude extracts against Curvularia sp., The pathogen of dirty panicle disease in rice. Faculty of Science and Technology. 37th Congress on Science and Technology of Thailand.

22. Ankita S, Kanika S (2011) Assay of Antifungal Activity of Lawsonia inermis Linn. and Eucalyptus citriodora Hook. Journal of Pharmacy Research 4: 1313-1314.

23. Ghaffar A (1969) Biological control of white rot of onion. Interaction effect of soil microorganisms with Sclerotium cepivorum. Mycopathologica at Mycological Application 38: 101-111.

24. Naik MK, Sen B (1995) Biocontrol of plant disease caused by Fusarium spp. In : Recent Development in Biocontrol of Plant Diseases 37-51.

25. Basha SUK (2002) Antagonism of Bacillus species (strain BC121) toward Curvularia lunata. Current Science 82: 1457-1463. 
Citation: Kithan C and Daiho L (2014) In Vitro Evaluation of Botanicals, Bio-Agents and Fungicides against Leaf Blight of Etlingera linguiformis Caused by Curvularia lunata Var. Aeria. J Plant Pathol Microbiol 5: 232. doi:10.4172/2157-7471.1000232

Page 6 of 6

26. Jat JG, Agalave HR (2013) Antagonistic properties of Trichoderma species against oil seed-borne fungi. Science Research Reporter 3: 171-174.

27. Kakde RB, Chavan AM (2011) Antagonistic properties of Trichoderma viride and Trichoderma harzianum against storage fungi. Elixir Appl. Botany 41: 5774-5778.
28. Patale SS, Mukadam DS (2011) Management of plant pathogenic fungi by using Trichoderma species. Bioscience Discovery 2: 36-37.

29. Dennis C, Webster J (1971) Antagonistic properties of species groups of Trichoderma II. Production of volatile antibiotics. Trans British Mycol Sac 57: 41-48. 